\title{
Petrographic Characterization of the Different Types of Basalts of Harrat Al Fatih, Ablah Area, West Central Arabian Shield, Saudi Arabia
}

\author{
Abdullah R. Sonbul' ${ }^{1}$, Ali A. Mesaed ${ }^{2,3}$ \\ ${ }^{1}$ Engineering and Environmental Geology Dept., Faculty of Earth Sciences, King Abdulaziz University, Jeddah, KSA \\ ${ }^{2}$ Geo-Exploration Techniques Dept., Faculty of Earth Sciences, King Abdulaziz University, Jeddah, KSA \\ ${ }^{3}$ Geology Department, Faculty of Sciences, Cairo University, Giza, Egypt \\ Email:dr.asonbul@Yhoo.com, alimesaed@yahoo.com
}

How to cite this paper: Sonbul, A.R. and Mesaed, A.A. (2017) Petrographic Characterization of the Different Types of Basalts of Harrat Al Fatih, Ablah Area, West Central Arabian Shield, Saudi Arabia. Open Journal of Geology, 7, 871-887.

https://doi.org/10.4236/ojg.2017.76060

Received: May 24, 2017

Accepted: June 27, 2017

Published: June 30, 2017

Copyright $\odot 2017$ by authors and Scientific Research Publishing Inc. This work is licensed under the Creative Commons Attribution International License (CC BY 4.0).

http://creativecommons.org/licenses/by/4.0/

\begin{abstract}
Harrat Al Fatih is located southwest of Ablah area, Assir terrain, southwestern Arabian Shield. It is present as black laterally extended horizontal basaltic sheet just overlying folded strata of the volcano-sedimentary succession of Ablah Formation (green mudstones, dolostones and green and red volcaniclastic red beds). These basalts are rift-related and represent part of the Oligo-Miocene basic volcanics of the western part of Saudi Arabia. The detailed field and microscopic description of these basalts enable the author to classify it into two main types: 1) Grey tuffaceous glassy basalts that present overlying the Ablah Formation. This basalt type is generally soft, bedded and intercalated with grey, green and red tuffaceous mudstones. Microscopically it composed of minute lath-like plagioclase and pyroxene crystals embedded in glassy groundmass. 2) Black olivine-rich basalts which are present in the topmost part of harrat $\mathrm{Al} \mathrm{Fatih}$ are generally black, hard and contain remarkable reddish brown oxidized olivine spots and some calcite and amorphous quartz domains. Under the microscope, this basalt type is microcrystalline and composed mainly of lamellar twined Ca-plagioclase and colored olivines and pyroxenes. The olivines show different stages of oxidation and formation of amorphous blood red iron-oxyhydroxides and black hematite. The present study revealed the formation of the grey basalts at the initial stages of the volcanic eruption in ephemeral lakes and the second type of basalt was during the consolidation of proper basic magmas at the final stages of the volcanic eruption.
\end{abstract}

\section{Keywords}

Harrat of Saudi Arabia, Geology of Ablah Area, Tertiary Volcanics of Saudi Arabia 


\section{Introduction}

\subsection{General Geology and Physiography}

Tertiary basic volcanics (Oligo-Miocene) are extended parallel to the Red Sea from the extreme NW in Jordan and Syria to the SE in Yemen. These volcanics are rift-related and are composed mainly from basalts and olivine basalts. The total volume of eruptive material in western Saudi Arabia is estimated to be 103 to $105 \mathrm{~km}^{3}$. The eruptive history of these rocks apparently spans from Oligocene time to the present. The first major pulse occurred during the early Miocene and was followed by a hiatus at the end of the early Miocene. Volcanic activity resumed during the middle Miocene present [1].

Saudi Arabia has approximately $80,000 \mathrm{Km}^{2}$ of lava fields, known as harrats. These are rift-related volcanic eruptions that predominated during the opening of the Red Sea (Oligo-Miocene) in the western part of Saudi Arabia. These volcanic flows are capping different rock units ranging in age from Precambrian to Quaternary. The most common volcanic fields in Saudi Arabia include harrat Rahat, Khayber, Al Thanyan and Kishb.

Ablah area is located in Al Baha District about $60 \mathrm{~km}$ southeast of Al Baha Airport "Figure 1(a) and Figure 1(b)". Topographically, it is of moderate topography where it is bounded from the west by the Assir Mountains and from the east by areas of law topography "Figure 1(a) and Figure 1(b)". The area is dissected by many dry and sometimes wet and flooded wadies i.e. Wadi Kohlah, Wadi Girshah, W. Raniyah and Wadi Tharad "Figure 1(a) and Figure 1(b)". Most of these wadies run in $\mathrm{N}$ to $\mathrm{NE}$ directions coming from the west and southwest directions and drain in wadi Raniyah which runs NE until Raniyah city. The geology of the Southern Hijaz Quadrangle and a generalized geologic map (Quadrangle I-210A) at a scale of 1:500,000 were carried out by [2]. [3] [4] [5] [6] and [7] have concentrated their work on the economic potential of many mineralized areas within the quadrangle. The oldest major subdivision of the metamorphic rocks is Jeddah group which includes the Girshah Andesite and Khutnah Formation. The Girshah andesite comprises andesite flows, interbeds of marble, pyroclastic beds, and lesser amounts of basalt, and dacite. The Khutnah Formation unconformably overlies the Girshah andesite consisting of basal conglomerate, tuff, marble and andesite flows. Both Girshah, and Khutnah Formations are folded gently along north-northeast trending axes. The Halaban group is represented by the Jerub Formation. The latter is completely contained within the major Ablah graben and separated from the older units by faults. It comprises andesite, rhyolite, pyroclastic marble, and smaller amounts of basalt, quartz latite, and dacite. It has been folded along north-south axes. Plutonic intrusions of diorite, quartz diorite, granodiorite, gabbro and granite have intruded the Jeddah group and older rocks. Those bodies were intruded on different stages and have been cut by andesite and aplite dikes.

\subsection{Aims of the Study}

The present study aims to give detailed field and microscopic characterization of 


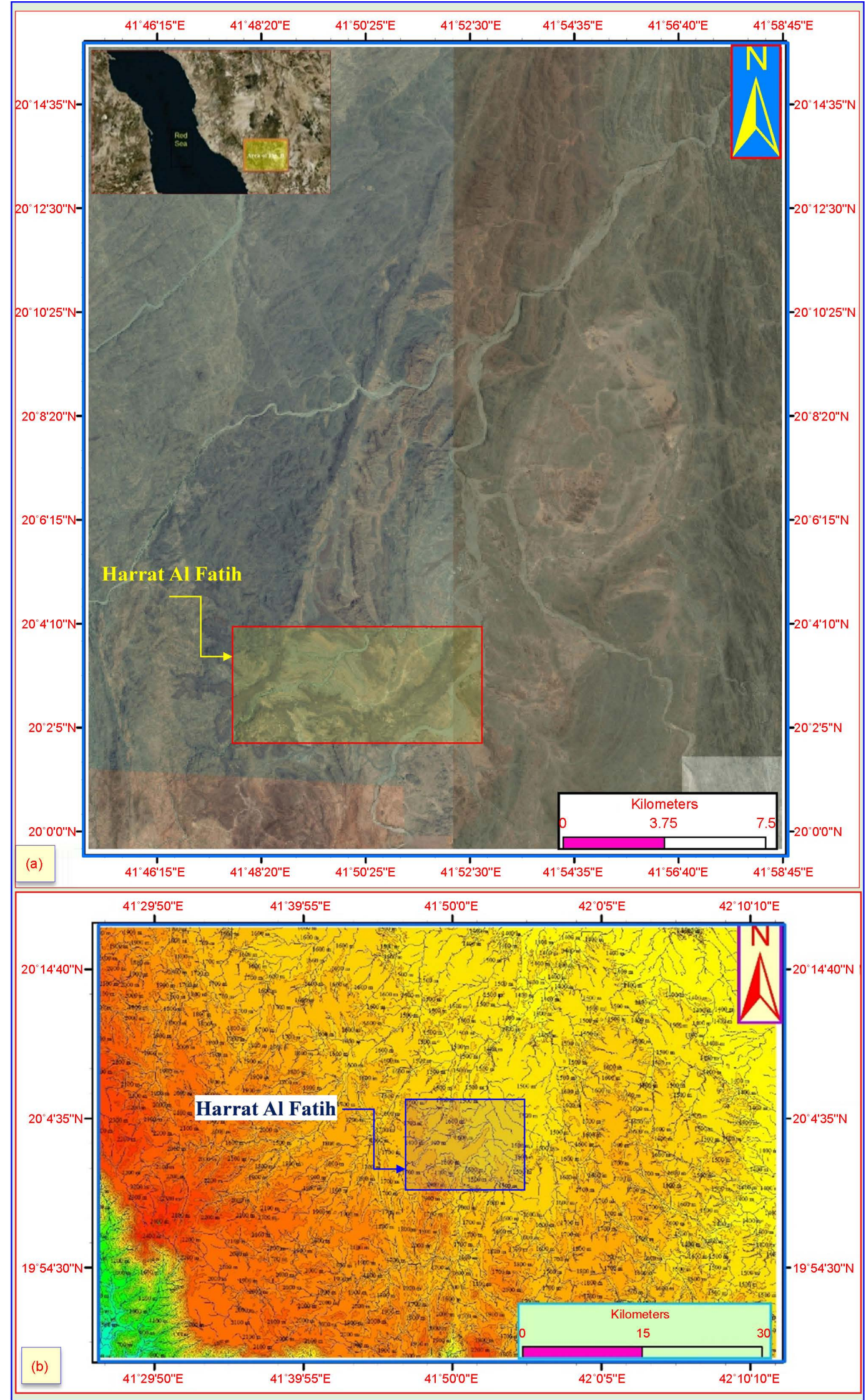

Figure 1. (a) = Google image of Ablah area; (b) = Contour satellite image of area of Figure 1(a). 
the different types of basalts of harrat Al Fatih area, southwest of Ablah area. The study also aims to describe the geologic events of the study area during the eruption of these basic volcanics.

\subsection{Materials and Methods}

In the initial stage of the study, the regional and detailed satellite images and geologic maps of the study area are prepared. The field works were carried out throughout three successive trips each one four days. Detailed stratigraphic section was measured for the complete section of harrat Al Fatih. The collected samples are used for thin section preparation. The thin sections are fully described and the different petrographic basaltic types are deduced.

\subsection{Detailed Geology and Geomorphology of Harrat Al Fatih Area}

Harrat $\mathrm{Al}$ Fatih represents a small black area covering the folded and faulted border of Ablah Formation to the south of Abu Kabir village. It is also covers vast area to the south of Wadi Kohlah. Harrat Al Fatih is a small part of the large lava fields in the southern part of Saudi Arabia. i.e. Harrat Haddan to the north of Ablah area "Figure 1(a) and Figure 1(b)". The detailed morphology of wadi Kohlah area and the surrounding black highlands of harrat $\mathrm{Al} \mathrm{Fatih}$ areas are illustrated in "Figures 2(a)-(c)". In Wadi Kohlah area, the green mudstones and carbonated lower parts of Ablah Formation are highly folded and faulted and have a stranger northwest strike in contrast to the general strike of Ablah Formation in Ablah graben in N-S direction "Figure 3(a) and Figure 3(b)".

\section{Stratigraphic Setting of Harrat Al Fatih in Wadi Kohlah}

Harrat Al Fatih represents very diagnostic black arcuate area trending in many irregular direction against the general trend of the underlying folded and faulted strata of Ablah Formation. On the satellite images of wadi Kohlah area "Figure 3(a) and Figure 3(b)", the volcanics of Harrat Al Fatih is characterized by black color covering a lighter parallel bedded folded and faulted beds of Ablah Formation "Figure 3(a) and Figure 3(b)". The succession of Ablah Formation in Wadi Kohlah "Figure 3(b)" is composed from interbedded green mudstone, dolostones, chertified dolostones, chert and basalt and andesite flows with intercalated volcaniclastic green and red beds "Figure 3(b)".

The complete succession of Ablah Formation in wadi Kohlah is composed mainly from older to younger of green mudstones and dolostones in the southwestern corner of wadi Kohlah which grades upwards into rhyolite, chertified yellow dolostones and finally into the volcaniclastic red beds in the northeastern part of wadi Kohlah "Figure 4(a)". It is observed that, the horizontal flat-lying basaltic sheet of harrat Al Fatih area overlies different rock units of the folded green mudstones and carbonates of the southwestern part "Figure 4(b)" and also truncates younger volcaniclastic red beds in the northeastern part of W. Kohlah "Figure 4(c)". 

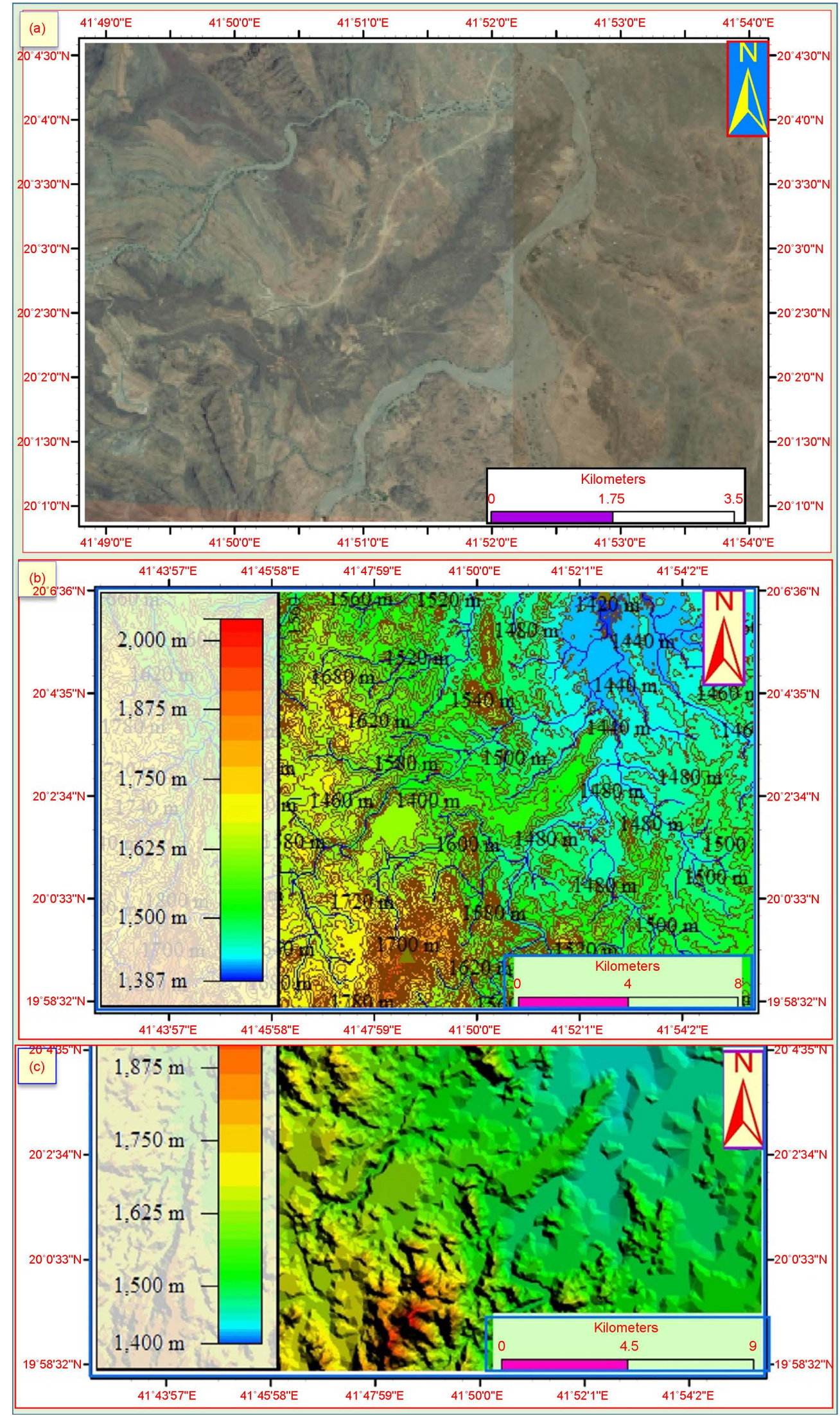

Figure 2. (a) = Satellite image of Harrat Al Fatih, (b) = Contour satellite image with drainage lines of Harrat $\mathrm{Al}$ Fatih, (c) = 3D satellite image of harrat Al Fatih area. 

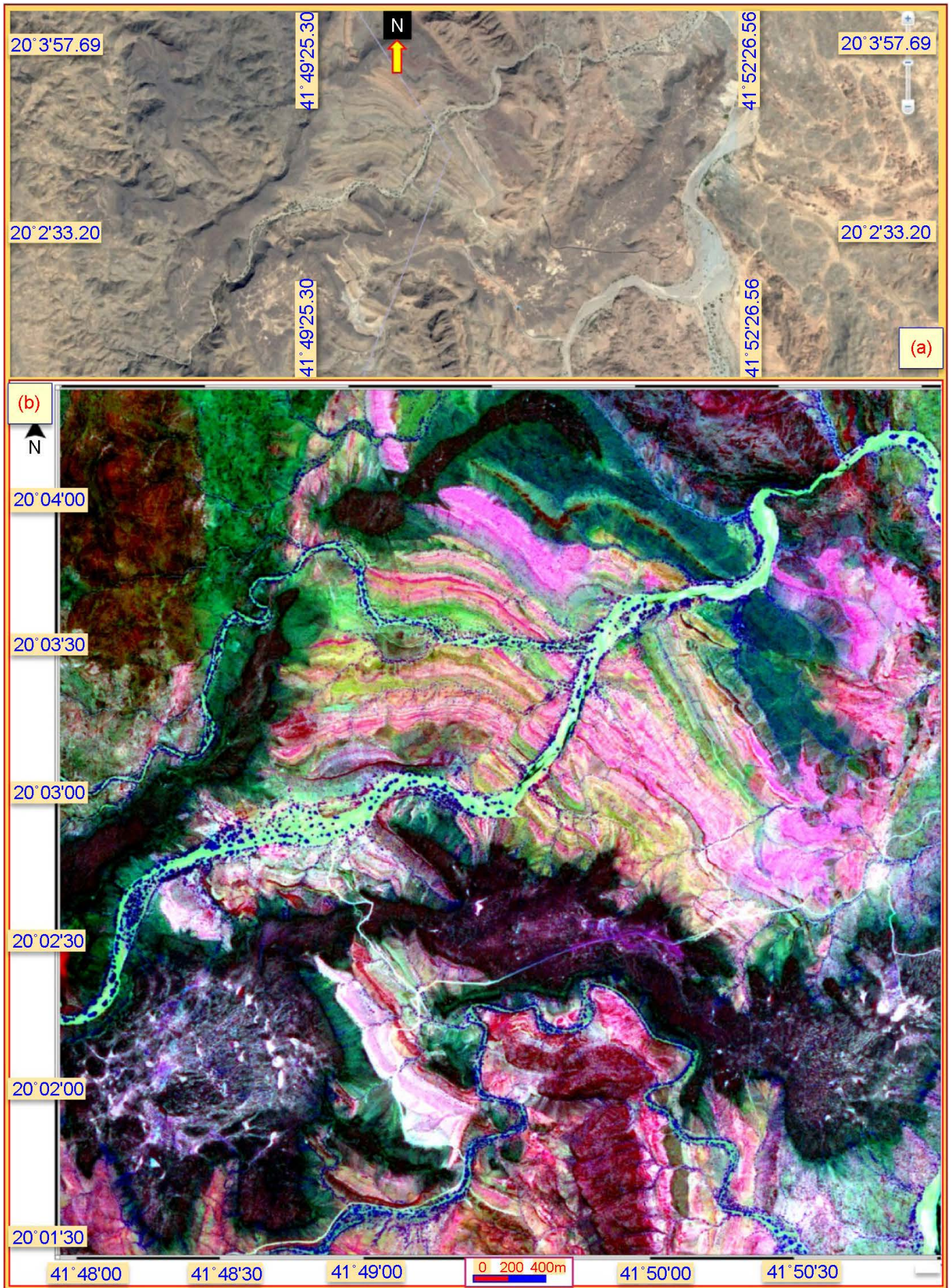

Figure 3. Google image (a) and satellite image (b) of Harrat Al Fatih area showing the light color folded and tilted carbonates of the lower part of Ablah formation in wadi Kohlah area.

The basic volcanics of Harrat Al Fatih are present in horizontal position that overlying the tilted folded and faulted strata of Ablah Formation showing a very fantastic angular unconformity "Figure 5(a) and Figure 5(b)". In this area, the succession of Ablah formation is intensively tilted by folding and faulting processes while basic volcanics of Harrat Al Fatih is present as horizontal flat 

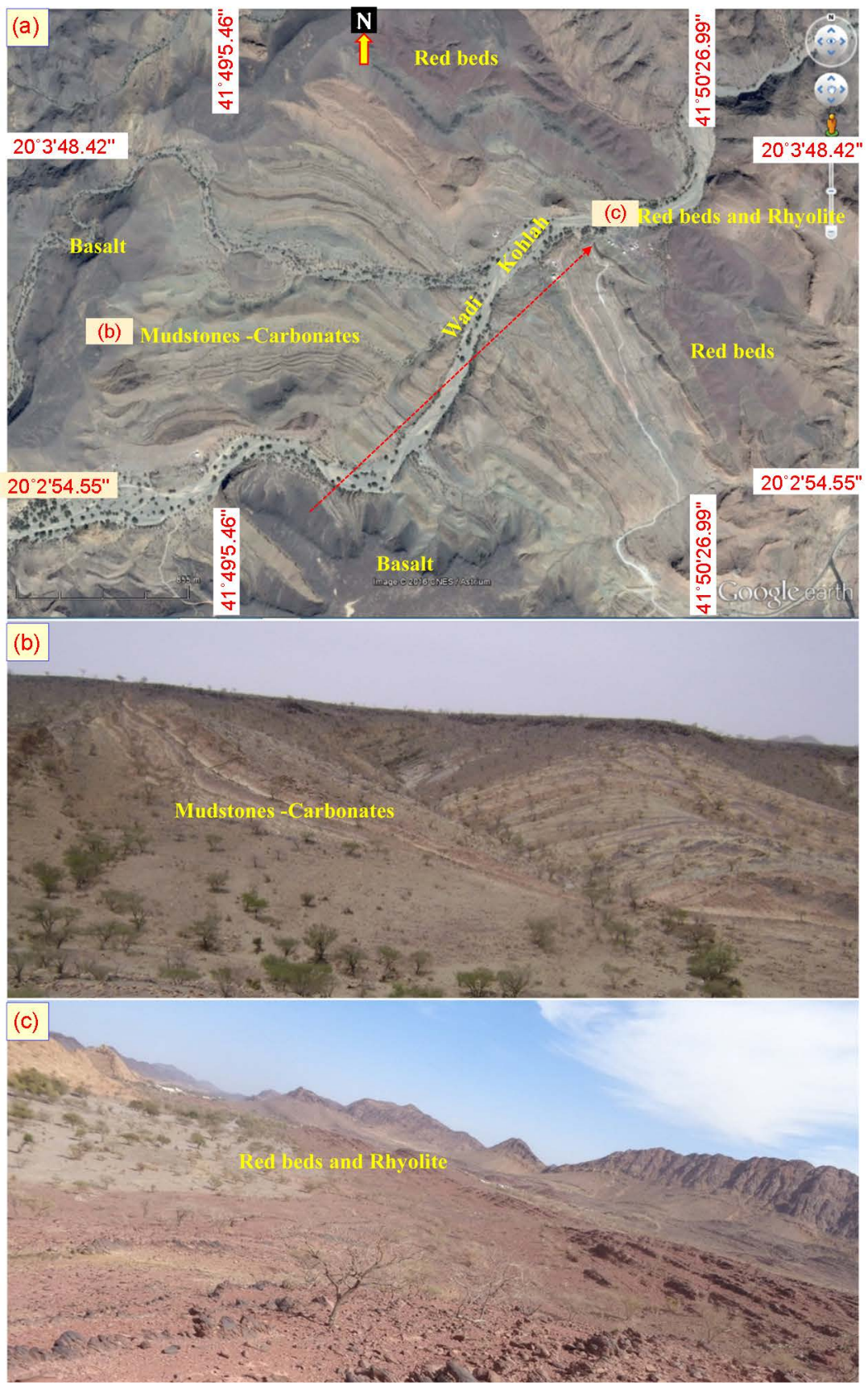

Figure 4. (a) = Complete succession of Ablah formation in wadi Kohlah grading from the older in the SW to the younger in the NE; (b) = Truncation of the older folded green mudstones and carbonates of the SW part of W. Kohlah by the black horizontal basaltic sheet of harrat Al Fatih; (c) = The younger folded volcaniclastic red beds and the overlying rhyolites of the northeastern part of Wadi Kohlah.

sheet "Figure 5(c)".

The contact line between the two units is irregular and above this line a horizontal strata of grey, green and red tuffaceous mudstone is present "Figure 6(a)". Above this tuffaceous mudstone succession, a very diagnostic columnar joints "Figure 6(b)". The topmost part is composed from black basalt sheet "Figure 6(c)". This succession was described to be formed by chemical weathering, 


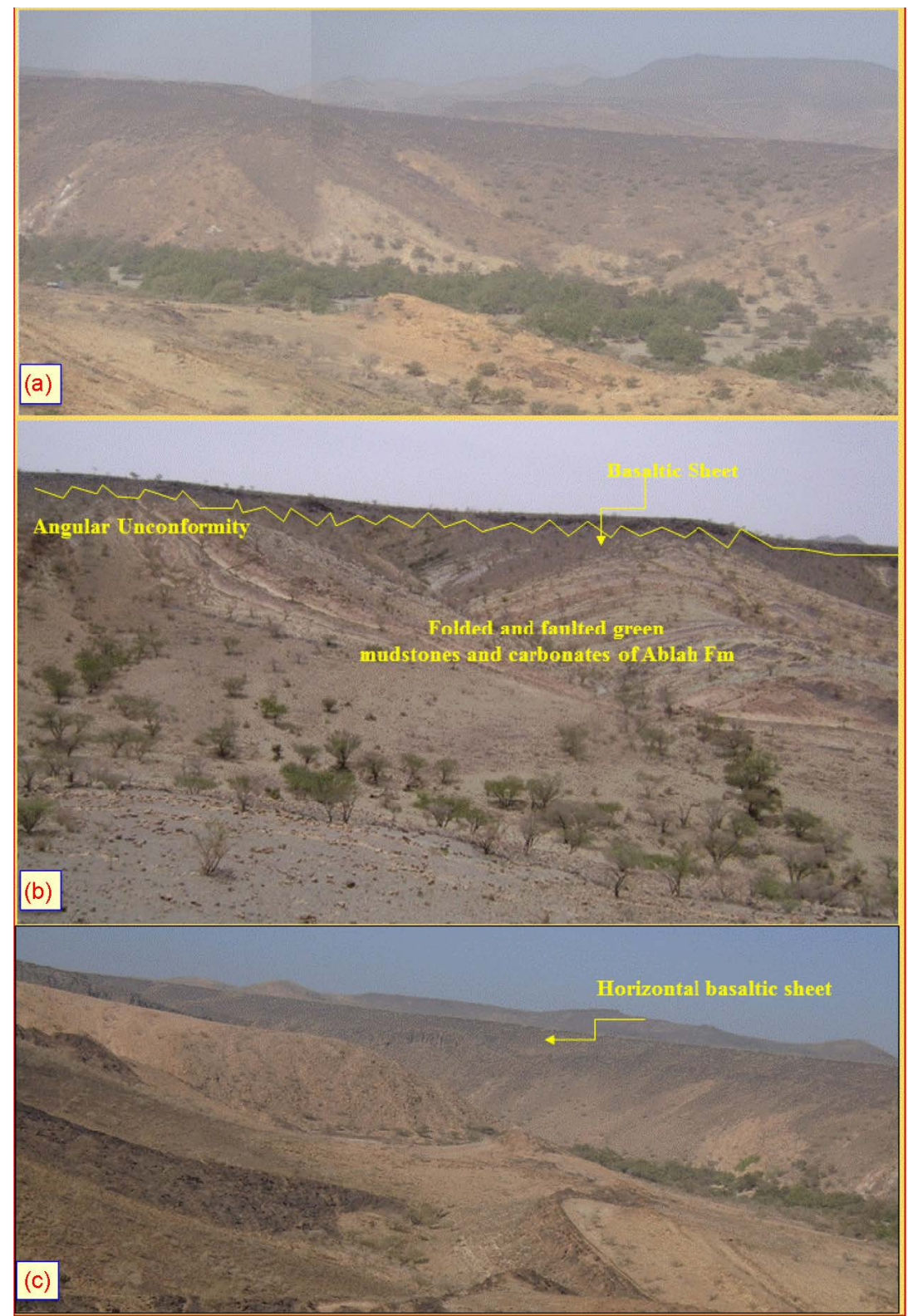

Figure 5. (a)-(c) = Horizontal black basalt sheet of Wadi Kohlah on tilted green clays and carbonates of Ablah Formation in W. Kohlah area.

which I believe is not true because the topmost basalt is fresh and there is doughts against the chemical weathering processes. This folded and faulted succession of Ablah Formation (about 620 m.y.) is exposed since post Precambrian time. Then the area was exposed for continental conditions before the eruption of the basaltic magma, many small continental lakes was formed above the irregular topography. During the filling of these lakes, the initial stages of volcanic eruption led to the eruption of ashes and gases which fill the continental lakes. A thick succession of tuffaceous mudstones were deposited under different water depths which led to the formation of grey, green and red tuffacoeuses mudstone. This was followed upward by glassy basalt of very diagnostic columnar joints "Figure 6(b)". 


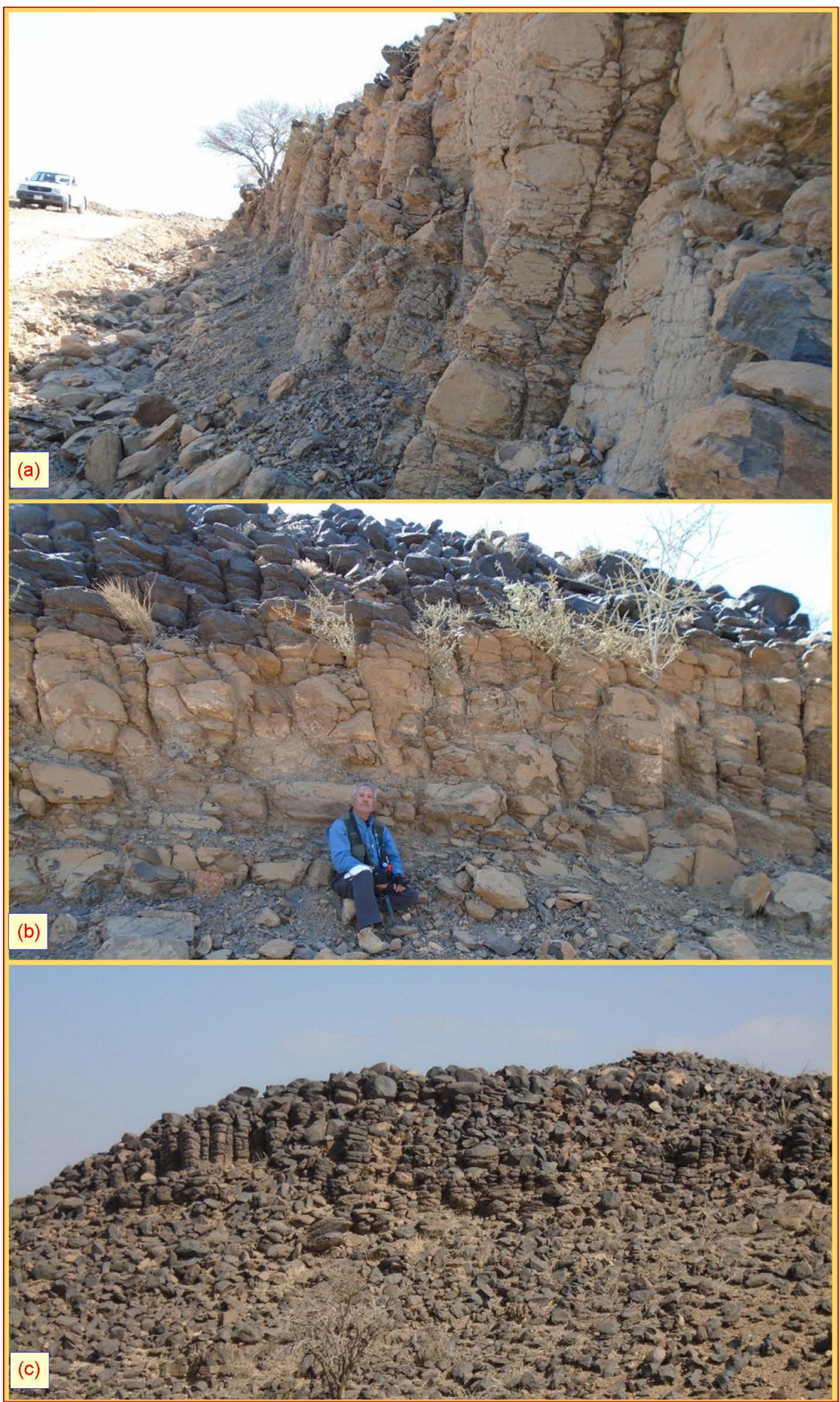

Figure 6. (a) = Horizontal bedded tuffaceous basalt and tuffaceous mudstone of the lower part of harrat Al Fatih. Notice the black basalt in the topmost part of harrat Al Fatih; (b) = Columnar jointed tuffaceous basalt in the lower part of Harrat Al Fatih area; (c) = Horizontally flat-topped basalt of Harrat $\mathrm{Al} \mathrm{Fatih} \mathrm{in} \mathrm{wadi} \mathrm{Halwate} \mathrm{area.}$

This characteristic glassy basalt unit represents initial stages of volcanic eruption and deposition of the tuffaceous materials within the volcanic ephemeral lakes. The subsequent stages of diagenetic modifications led to the volcaniclastic 
green and red beds below the proper basaltic sheet in the topmost part of the succession. Similar conclusion for the origin of the volcaniclastic green and red beds have been reached by [8] [9] [10] and [11]. The topmost black basaltic sheet was formed by proper basic lava flows during the final stage of volcanic activity.

\section{W. Halwate Area}

W. Halwate "Figure 7(a)" is a North-South Wadi runs parallel to W. Raniyah. The geology and geomorphology of Wad Halwate appear in the published paper of [11]. In this area, the Harrate are present as black flat-lying sheet "Figure 7 (b)" on the inclined strata of red and green volcaniclastic beds of units 7, 8 respectively of [11]. In the western part of Wadi Halwate, the flat-lying basaltic sheet cross-cuts the yellow carbonate unit No. 6 of [11]. This horizontal sheet covered fast black area at the intersection of Wadi Halwate with Wadi Kohlah "Figure 7(b)".

\section{Field, Mega and Microscopic Description}

The close up investigation of the basaltic sheet of Wadi Halwate area revealed
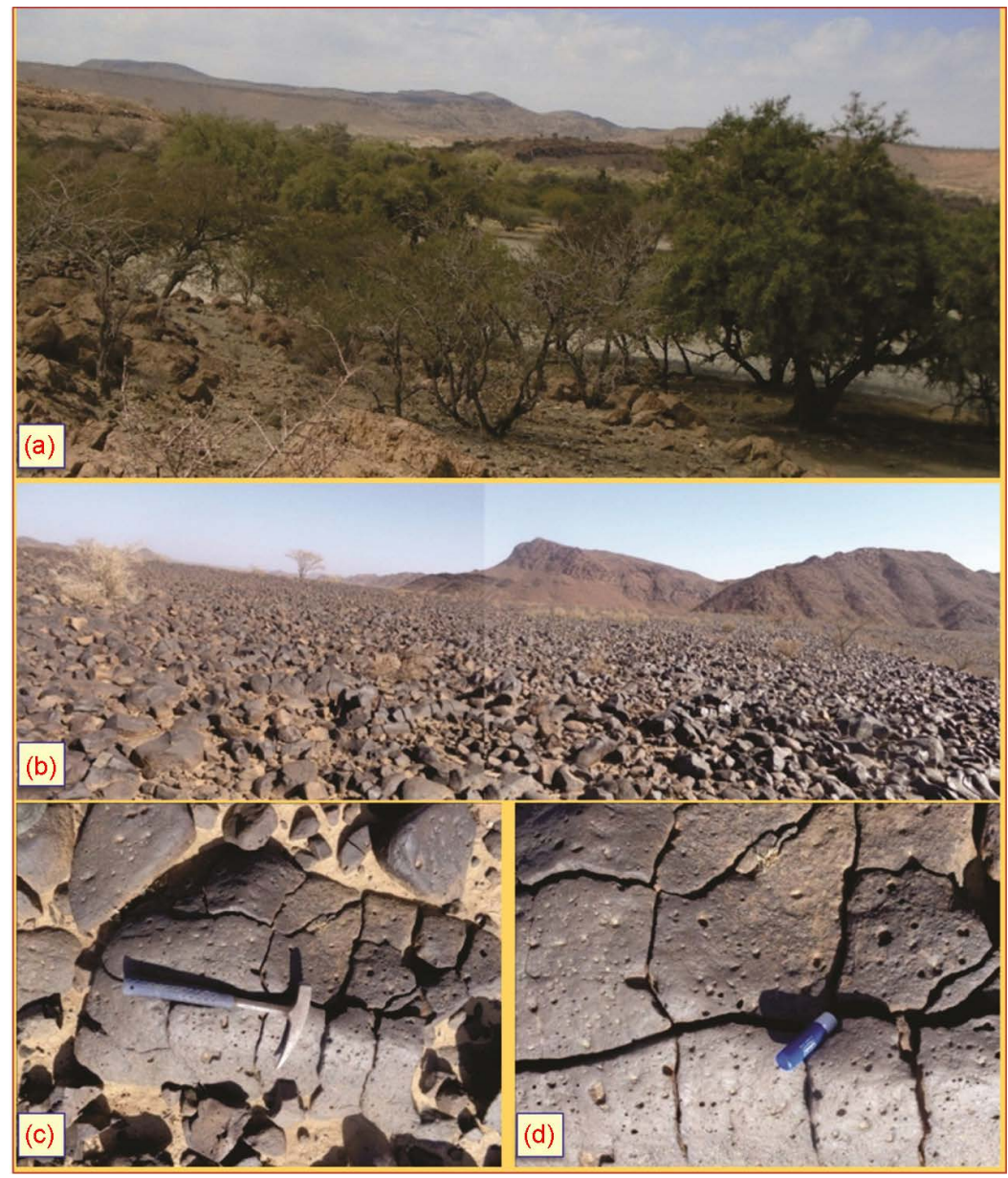

Figure 7. (a), (b)= Horizontally flat-topped basalt of Harrat Al Fatih in Wadi Halwate area; (c), (d) = Cracked and fractured olivine vesicular basalt of the upper part of basalt of harrat Al Fatih in Wadi Halwate area. 
the presence of two main horizons "Figure 8", which are similar to those described in Wadi Kohlah area. These horizons are: 1) Lower friable tuffaceous mudstone and grey glassy basalt unit. This unit ranges in thickness from 1 to 3 $m$ thick; 2) the topmost black hard vesicular basalt unit which ranges in thickness from 2 to $6 \mathrm{~m}$ thick. This basalt is coarse crystalline and it is either of vesicular or amygdaloidal texture "Figure 7(c) and Figure 7(d)". It contains numerous green olivine spots and/or reddish brown patches and domains "Figure 7 (c) and Figure 7(d)". White color patches and veinlets are also recorded. The detailed microscopic description of the prepared thin sections of the black upper unit revealed presence of the following petrographic lithotypes.

\section{1) Glassy Basalt}

Glassy basalt forms the most common petrographic lithotype. It consists mainly of small prismatic Ca-plagioclase crystals and crystallites, small minute

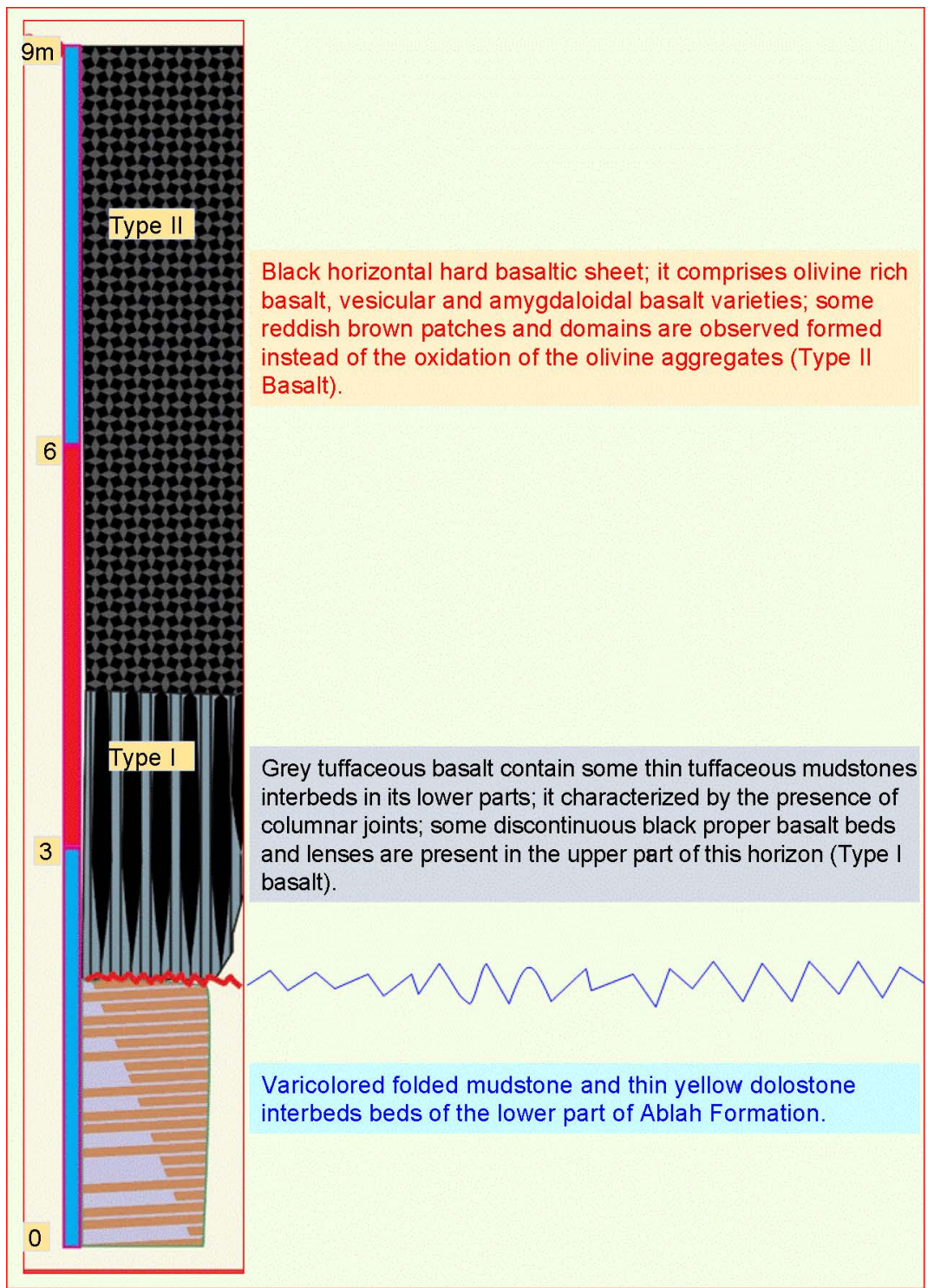

Figure 8. Stratigraphic section showing the two types of basalts of harrat Al Fatih area. 
pyroxene crystals and amorphous non crystalline glassy tuffaceous materials "Figures 9(a)-(d)". The Ca-plagioclase crystals are usually coarse crystalline and flow in on direction forming trachytic or flow texture "Figure 9 (c) and Figure 9(d)". In this type of basalt, white color calcite domains are observed (Figure 9(c) and Figure 9(d)). These calcite domains are most probably formed by the calcitization of the Ca-plagioclase crystals as well from the Ca-rich glassy matrix.

Blood red iron-oxyhydroxides patches and domains observed admixed with the other constituents of the basalt "Figure 9(e) and Figure 9(f)". Close up microscopic observations revealed the presence of huge amount of dark brown to black goethite and hematite subhedral crystallites "Figures 10(a)-(d)". The detailed investigation supported the formation of black crystallites by the progressive oxidation of the associated pyroxene crystals. This is evidenced by the following:

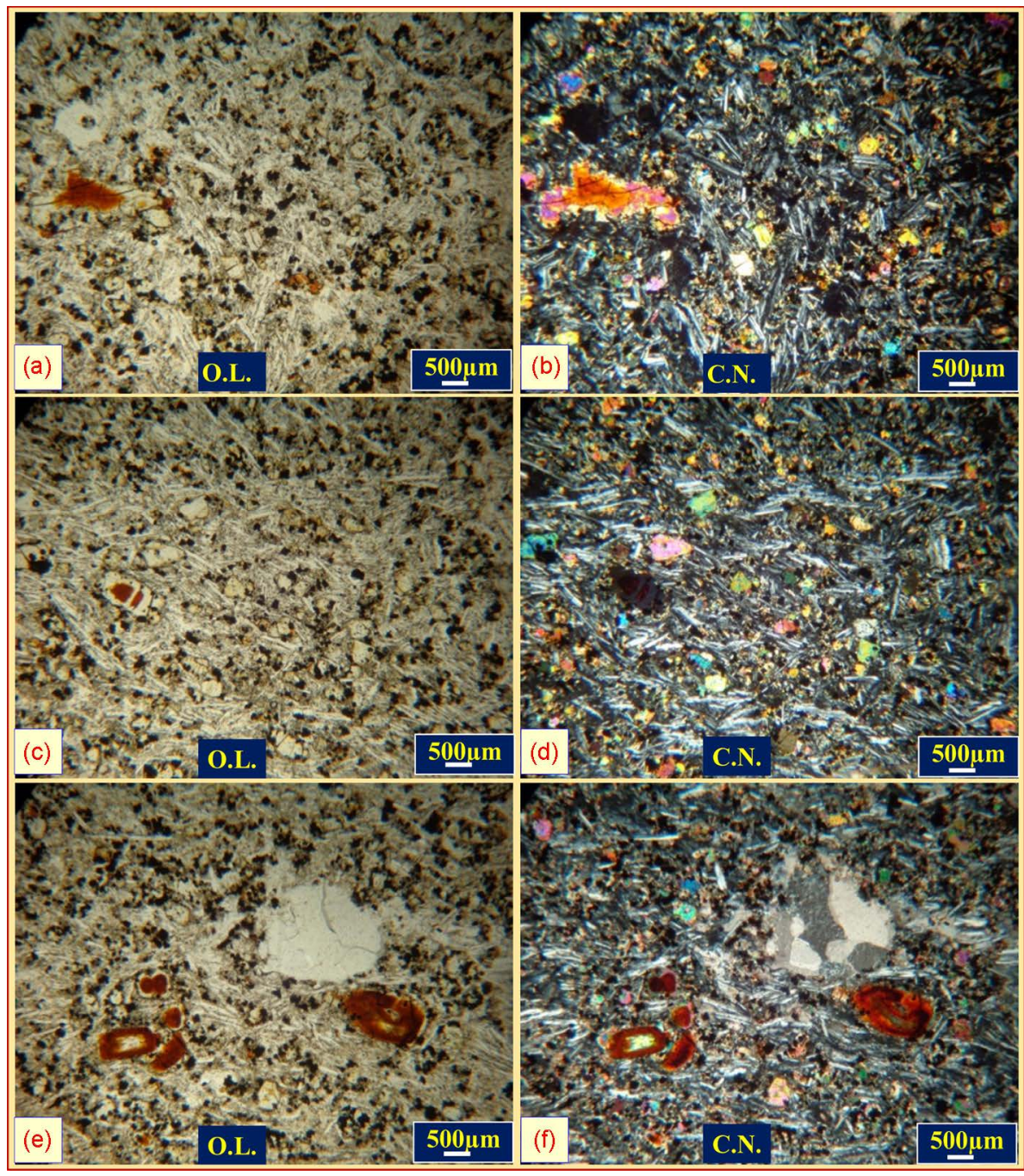

Figure 9. (a)-(d) = Small prismatic Ca-plagioclse crystals and crystallites and small minute pyroxene crystals and amorphous non crystalline glassy tuffaceous basalt; (e), (f) = Blood red iron-oxyhydroxides patches and domains are observed admixed with the other constituents of basalt. These blood red amorphous iron oxyhydroxides were formed instead of rounded and ellipsoid of olivine crystals with relicts of green second order interference color in the core of olivine crystals. O.L. = Ordinary Light, C.N. = Crossed Nicols. 
1) These black bodies are of the same size and shape of the fresh unaltered pyroxene crystals "Figures 10(a)-(f)"; 2) The presence of slightly altered pyroxene crystals which contain blood red amorphous iron-oxyhydroxides patches and domains "Figures 11(a)-(d)"; 3) The progressive hematitization of the blood red amorphous iron-oxyhydroxides into black hematite "Figure 11(e) and Figure 11(f)"; and 4) The coalescence of the small hematite crystallites and formation of large black patches instead of the different constituents of the oxidized basalt "Figure 11(e) and Figure 11(f)".

\section{2) Olivine Basalt}

This type of basalt is present in the topmost part of Harrat Al Fatih. It is characterized by presence of olivine crystals "Figures $12(\mathrm{a})$-(d)". The olivine crystals are almost of rounded and ellipsoidal shape. They commonly cracked in radial or intersected pattern. Along these cracks, the olivine crystals are slightly altered into iron oxides "Figures 12(a)-(d)". These large olivine crystals are
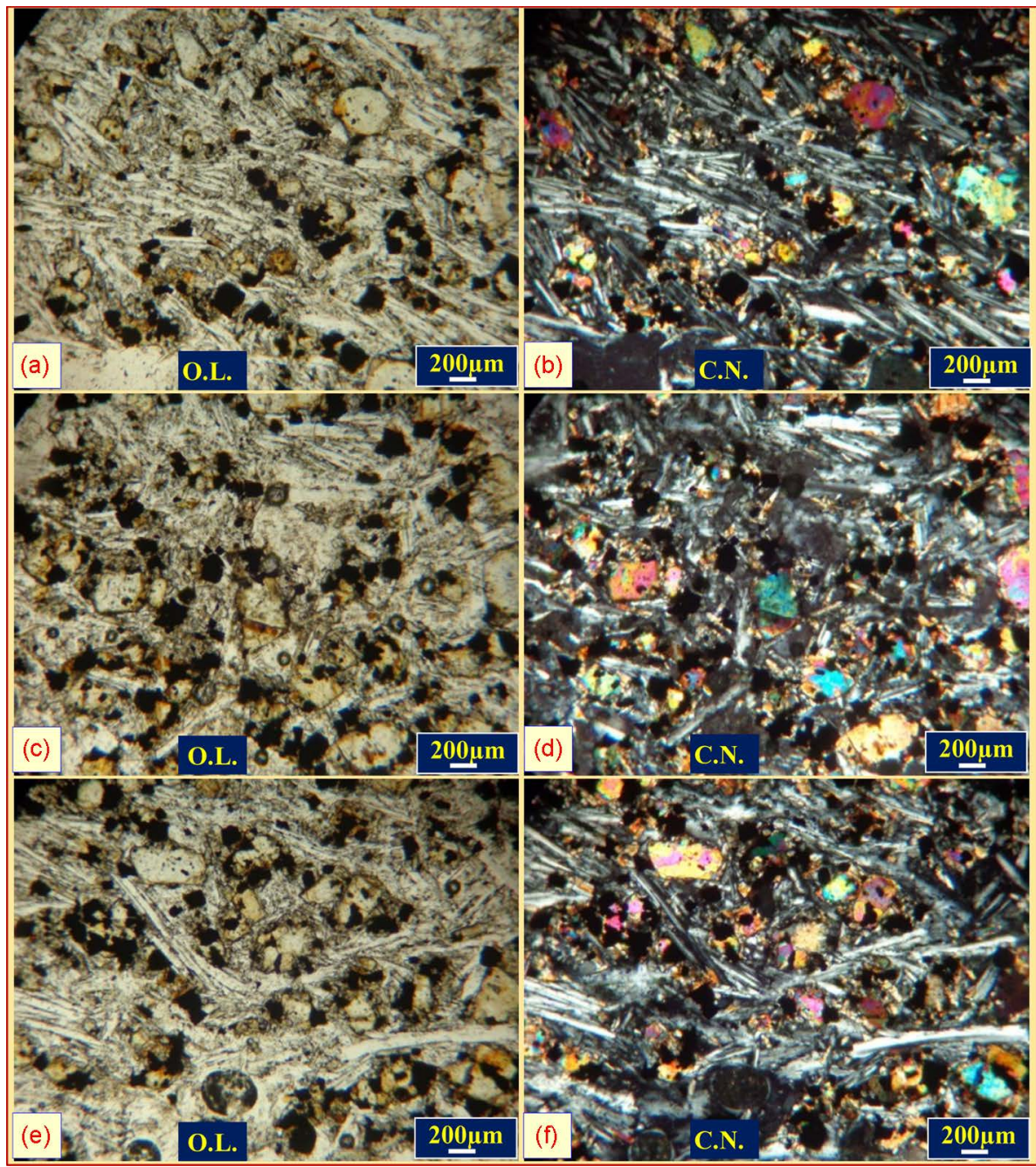

Figure 10. (a)-(d) = Black huge amount of dark brown to black goethite and hematite subhedral crystals formed by the progressive oxidation of the associated pyroxenes crystals; (e), (f) = The black crystals are of the same sizes and shapes of the precursor unhematitized olivine crystals. 

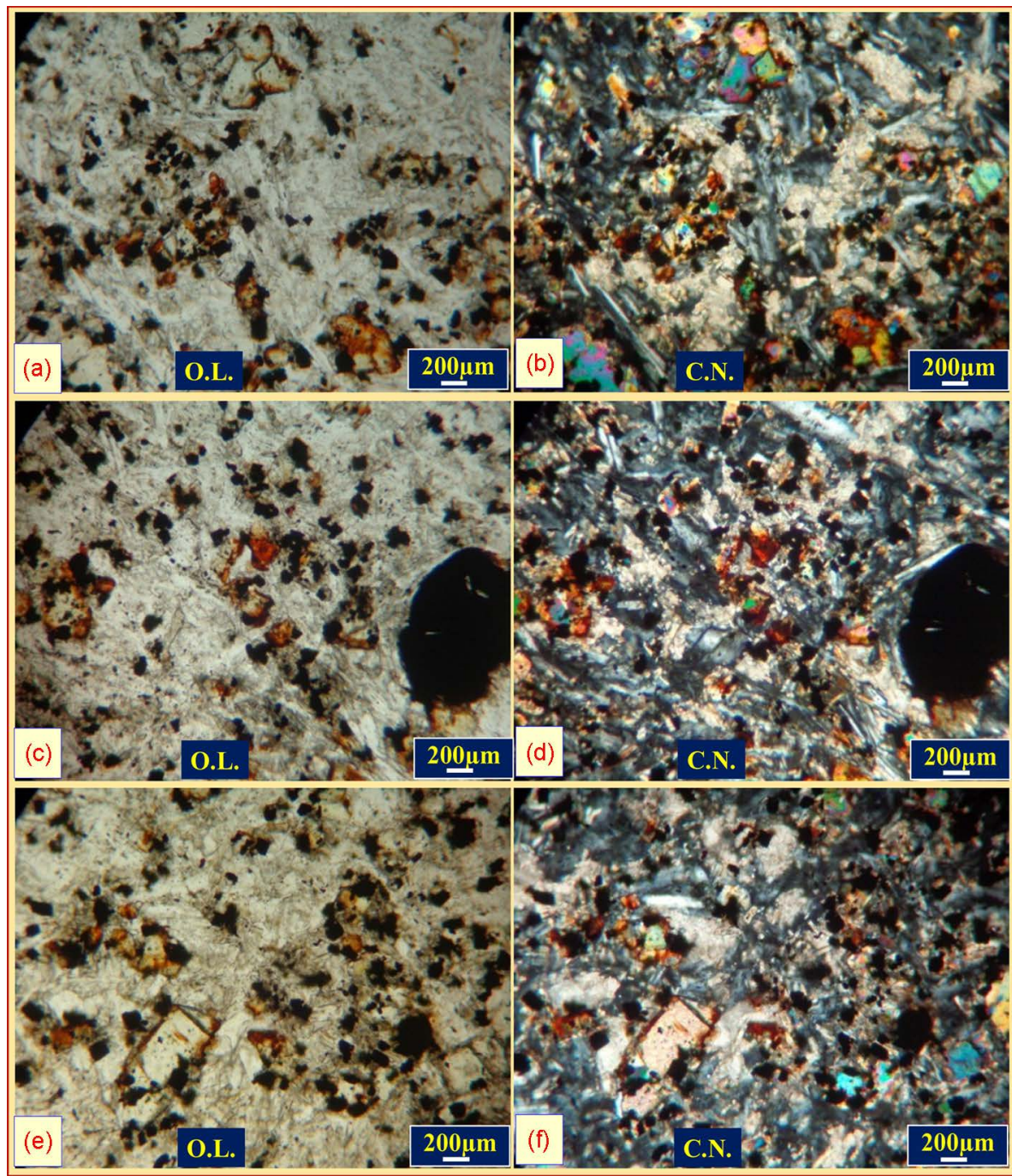

Figure 11. (a)-(d) = The presence of blood red amorphous iron-oxyhydroxides crystals of the same sizes and shapes of the black hematite crystals and the colored precursor unaltered olivine crystals which indicate its formation during mid-stage of oxidation; (e), (f) = Progressive hematitization of the blood red amorphous iron-oxyhydroxides into black hematite.

embedded in highly oxidized pyroxene crystals and calcitized Ca-plagioclase crystals. The olivine crystals are intensively oxidized in many forms i.e. peripheral hematitization "Figures 12(a)-(d)", zonal hematitization "Figure 12(e) and Figure 12(f)" and complete or entire hematitization "Figure $12(\mathrm{~g})$ and Figure 12(h)". All the hematitization forms were carried out by the conversion of olivine into amorphous blood red iron oxyhydroxides into brown goethite and finally into hematite.

\section{Discussion and Conclusions}

The present field observations revealed that, harrat $\mathrm{Al}$ Fatih represents black horizontal basaltic sheet overlying tilted strata of the volcaniclastic succession of Ablah Formation in Wadi Kohlah area. Microscopically, it comprises two main types of basalts i.e. lower grey glassy immature basalts and upper black proper 


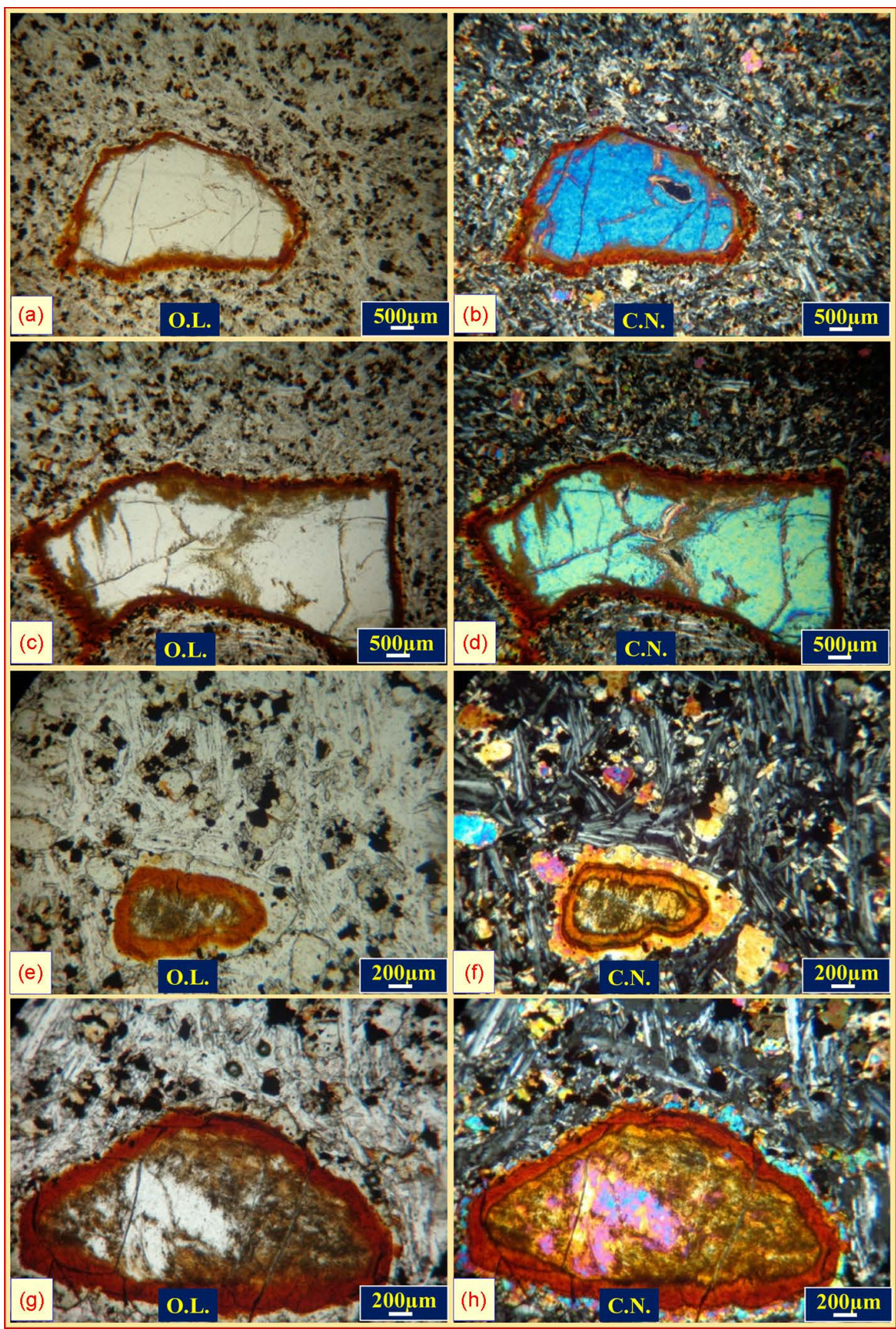

Figure 12. (a)-(h) = Olivine-rich doleritic basalt in the topmost part of Harrat Al Fatih. The olivine crystals are almost of rounded and ellipsoidal shape and are commonly cracked in radial or intersected pattern and along these cracks the olivine crystals are slightly altered into iron oxides. These large olivine crystals are embedded in highly oxidized pyroxene crystals and calcitized Ca-plagioclase crystals. The olivine crystals are intensively oxidized in many forms i.e. peripheral hematitization (Figures 12(a)-(d)), zonal hematitization (Figure 12(e) and Figure 12(f)) and complete or entire hematitization (Figure 12(g) and Figure 12(h)). All the hematitization forms were carried out by the conversion of olivine into amorphous blood red iron-oxyhydroxides then into brown goethite and finally into hematite.

basalts. The lower grey glassy basalt is bedded and composed mainly from fine crystalline Ca-plagioclase and palagonite embedded in dense glassy matrix 
enriched with iron oxyhydroxides. This type of basalt is formed during the initial stages of the volcanic eruptions and deposition of the fine volcanic derivatives in shallow fresh water lakes that formed in the areas in between the volcanic source areas. The upper black olivine-rich basalts are composed mainly from Ca-plagioclase, pyroxenes and olivine. This type of basalt was formed during the crystallization of the basic lava erupted during the final stages of volcanic activities. The oxidation of the ferromagnesian mineral of this basalt indicates their crystallization in surface oxygenated conditions. The two basalt types are laterally extended the area surrounding Wadi Kohlah. In the area south of Wadi Kohlah, the studied Tertiary basalt succession changed laterally into lower thick red and black scoriaceous basalt which overlain by olivine-rich basalt. This indicated the dependence of the textural and mineralogical composition of basalt on the paleo-geologic conditions predominated during the location of the volcanic eruption.

\section{Acknowledgements}

The author submits deep thanks for the Faculty of Earth Sciences "FES", King Abdulaziz University "KAU" for the field and lab facilities. Also, my thanks are extended to the editors of the OJG for the revision and editing of the manuscript.

\section{References}

[1] Coleman, R.G., Gregory, R.T. and Brown, G.F. (1983) Cenozoic Volcanic Rocks of Saudi Arabia. Open-File Report 83-788. Prepared for Ministry of Petroleum and Mineral Resources, Deputy Ministry for Mineral Resources Jeddah, Kingdom of Saudi Arabia.

[2] Brown, G.F., Jackson, R.O., Bogue, R.G. and Maclean, W.H. (1962) Geology of the Southern Hijaz Quadrangle, Kingdom of Saudi Arabia: U.S. Geol. Survey Misc. Geol. Inv. Map I-201A.

[3] Goldsmith, R. (1966) Mineral Resources of the Southern Hijaz Quadrangle, Kingdom of Saudi Arabia: U.S. Geol. Survey Saudi Arabia Project. Tech. Ltr., 78, 6-17, 51 , and $72-74$.

[4] Trent, V.A. (1966) Mineral Investigations in the Aqiq Area, Saudi Arabia: U.S. Geol. Survey Saudi Arabian Project. Tech. Ltr., 38.

[5] Trent, V.A. and Sultan, G.H. (1966) A Geological and Mineral Reconnaissance of the Ablah Formation and the Kamdan Anomaly, South Agig Area, Saudi Arabia: U.S. Geol. Survey Saudi Arabian Project. Tech. Ltr., 68.

[6] Theobald Jr., P.K. and Thompson, C.E. (1966) Geology and Geochemistry of a Part of the Ablah Formation Rumur, Kingdom of Saudi Arabia: U.S. Geol. Survey Saudi Arabian Project. Tech. Ltr., 88.

[7] Allcott, G.H. (1969) Diamond Drilling at Ablah Ancient Mine: Annual Report of the Directorate General for Mineral Resources. Saudi Arabia, (September 1968 to September 1969), 32-43.

[8] Mesaed, A.A. (2004) Mechanism of Formation of the Upper Eocene Glauconitic Ironstones and Red Beds of Gabal Qalamoon Area, Western Desert, Egypt. Egyptian Journal of Geology, 48, 17-44.

[9] Taj, R.J., Mesaed, A.A., Moufti, A., Qari, M.A.T. and Matsah, M.I. (2010) Origin 
and Diagenetic History of the Fluvio-Lacustrine/Deltaic Volcaniclastic Red Beds, W. Girshah-W. Halwate, Ablah District, Western Arabian Shield, Saudi Arabia. Proceedings of the Fifth International Conference on the Geology of the Tethys Realm, South Valley University, 227-248.

[10] Asaad, M. and Ali, M. (2015) Origin and Geochemistry of the Late Proterozoic Intra-Arc Rift-Related Volcaniclastic Red and Green Beds of Tayibit El Esm Area, Ablah District, South Central Arabian Shield, Saudi Arabia. Arabian Journal of Geosciences, 8, 7515-7536. https://doi.org/10.1007/s12517-014-1675-5

[11] Rasheed, S.A. (2016) Field, Mega and Microscopic Description of the Volcaniclastic Red Beds and the Associated Scoriaceous Basalt of Wadi Al Roaian, Ablah Area, Assir Terrain. Open Journal of Geology, 6, 598-616.

https://doi.org/10.4236/ojg.2016.67047

Submit or recommend next manuscript to SCIRP and we will provide best service for you:

Accepting pre-submission inquiries through Email, Facebook, LinkedIn, Twitter, etc. A wide selection of journals (inclusive of 9 subjects, more than 200 journals) Providing 24-hour high-quality service User-friendly online submission system Fair and swift peer-review system Efficient typesetting and proofreading procedure Display of the result of downloads and visits, as well as the number of cited articles Maximum dissemination of your research work

Submit your manuscript at: http://papersubmission.scirp.org/

Or contactojg@scirp.org 